\title{
Ebola-2014 - A Case of Fictional Reality?
}

\author{
Chetan Datta Poduri
}

Department of Biotechnology, SreeNidhi Institute of Science \& Technology (SNIST), India

Copyright $(\mathrm{C} 2016$ by authors, all rights reserved. Authors agree that this article remains permanently open access under the terms of the Creative Commons Attribution License 4.0 International License

\begin{abstract}
As per UNAIDS database, India has the World's third largest population of people living with HIV infection. Nigeria is second in position in this list of people living with HIV. This observation is significant for the simple reason that Nigeria is also presently affected with the recent Ebola epidemic (Ebola-2014). The West African region, to which Nigeria belongs, suffers the Ebola-2014 from a different strain of Ebola virus as compared to a concurrent epidemic in Equatorial African nation of Democratic Republic of Congo (DRC). Presented in this article is an analysis of the documented literature on this multi-dimensional Ebola-2014 epidemic. The mystifying phenomenon of persistence of the epidemic in West Africa is explained through various aspects attributable to the geopolitics of the region, biology of the virus, funeral customs in the region, fiction, economics and conspiratorial theories.
\end{abstract}

Keywords Ebola, Africa, Epidemic, GDP, Revenue, MNC, Fiction, Conspiracy

\section{Prelude}

The year 2014 witnessed two concurrent Ebola viral epidemics that rocked the world. Research reveals that these two episodes were caused by two different but related strains of Ebola virus. While the epidemic in Democratic Republic of Congo (DRC) conforms to the established characteristics of an Ebola epidemic, the one in West Africa baffled researchers by its sheer magnitude, persistence, sustenance and spread (involving at least four nations). This situation prompted many-a-journalist to compare the situation with those documented in fiction to dispel rumors about the virus. Also, very few articles took into account the economics involved. One author proffers 'poverty' as an answer to regular epidemics of Ebola that plague Africa [1]. A deeper look into the economics of the affected countries cost of developing and marketing viable vaccines, and revenues of multi-national pharma-biotech companies points to something sinister whence it appears as if life is mimicking fiction.

\section{Materials and Methods}

In the present article, the epidemics of Ebola, henceforth referred to as Ebola-2014, is analyzed from biological, fictional and conspiratorial angles. The intention here is to cover aspects associated with Ebola-2014 previously not broached upon. In this process the aim is to bring to light the multi-dimensional nature of Ebola-2014. For accessing information, various internet resources and databases like Academic OneFile Infotrac (authors' personal membership at the British Council Library, Hyderabad, India), PubMed, Google Scholar, were used.

\section{Discussion}

\subsection{Stories}

A number of Science fiction novels and movies come close to describing scenarios similar to the Ebola-2014 situation. Most notable among those are briefly summarized here and differences, if any, to the Ebola-2014 situation, highlighted.

A Hollywood blockbuster movie titled "Mission Impossible II" (MI2) released in the year 2000, in fact seeds the idea of a conspiracy being afoot in Ebola-2014, particularly in West Africa. This movie, as per an article in the internet, is loosely based on another movie titled 'Notorious' (Directed by Alfred Hitchcock; released in 1946). Briefly, in MI2, the protagonist (Tom Cruise), a spy, is asked to bust the pharma-biotech company - underworld nexus. Also, the hero is asked to destroy a German-made-chimera virus which the Biotech Company wants to be released into the public domain with help of the underworld so that the general public is infected with the chimera. Once infected with the chimera, the patients develop symptoms akin to hemorrhagic fever (HF). The reason behind this nefarious activity is to increase the demand for a therapeutic drug developed by the company (called 'bellerofone' in the movie; see Endnotes 1) against the chimera. In reality, as per the movie plotline, there is no natural virus for which bellerofone can act; hence a necessity to release the chimera. Such a release of the 
chimera, the company hopes, will also have a ripple effect in spiking the price of company shares in the stock market. In this process, millions of dollars change hands before the hero can strike. A love triangle involving the underworld don, the don's girl friend and the hero is also interwoven into the plot to pep up the thrills (Source: imdb.com).

Robin Cook is said to have introduced the word 'medical' to the 'thriller' genre of fiction. Boston in the United States of America (USA) is the site of action for many of his novels. In a novel published in 1987, titled 'Outbreak', a series of epidemics involving Ebola virus occur sporadically throughout Boston and USA. However, all these epidemics are caused by the same strain of Ebola virus. This is where Cook's novel deviates from Ebola-2014 (Source: robincook.com). There is another book titled 'The Hot Zone' by Richard Preston (published in 1989) wherein the offending organism is again Ebola virus. But opinion is divided as to whether 'The Hot Zone' is fiction or non-fiction, and hence this book is dealt in the next section.

\subsection{Naturally Ebola!}

Quick facts associated with Ebola virus are listed in Table 1.

Table 1. Ebola virus at a glance.

\begin{tabular}{|c|c|}
\hline First report & 1976 \\
\hline Order & Mononegavirales \\
\hline Family & Filoviridae \\
\hline Genus & Ebola virus \\
\hline Species & $\begin{array}{l}\text { Five. Ebola Reston (1989) (non-pathogenic in humans); Bundibugyo } \\
\text { Virus (2007), Ebola Sudan (1976), Ebola Zaire (1976), Tai-Forest } \\
\text { Ebola virus or Ebola Iv ory Coast (1994). } \\
\text { Numbers in parentheses indicate the year of first report. }\end{array}$ \\
\hline Virus particle & Enveloped, $80 \mathrm{~nm}$ (diameter) $-1.1 \mu \mathrm{m}$ (length), form: twisted filaments \\
\hline Nucleic acid & $\begin{array}{l}\text { Non-segmented (-) single stranded RNA, 19kb, 5' Methyl cap, } \\
\text { 3' Poly A tail }\end{array}$ \\
\hline Proteins & $7[\mathrm{NP}, \mathrm{vp} 35, \mathrm{vp} 40, \mathrm{GP}, \mathrm{vp} 30, \mathrm{vp} 24, \mathrm{~L}]$ \\
\hline Host & Humans, primates, sylv atic animals (?) \\
\hline Reservoirs & $\begin{array}{l}\text { Wild bats (?), Cynomolgus monkeys (?), pigs, unidentified sylvatic } \\
\text { animals }\end{array}$ \\
\hline Disease & $\begin{array}{l}\text { Referred to as Ebola virus Disease (EVD) characterized by } \\
\text { Hemorrhagic fevers (HF) typified by copious internal bleeding, rapidly } \\
\text { progressing to death. }\end{array}$ \\
\hline Transmission & $\begin{array}{l}\text { Contact (Person-to-person \& Animal-to-person), sexual transmission, } \\
\text { contact with infected cadavers, airborne transmission (not the primary } \\
\text { route; see text), contaminated body fluids, needles \& hospital } \\
\text { equipment. }\end{array}$ \\
\hline Carriers status & Exists both in humans and animals \\
\hline Treatment/vaccines & Under trials \\
\hline Additional points & Category A bioterrorism agent \\
\hline $\begin{array}{l}\text { Information } \\
\text { collated from } \\
\text { (sources) }\end{array}$ & 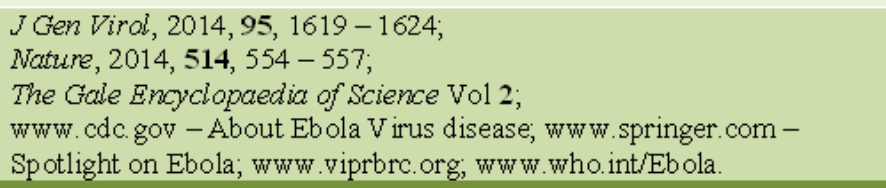 \\
\hline
\end{tabular}


One hallmark of the disease caused by Ebola virus, referred to as Ebola virus disease (EVD), is the rapid progression of the affected individuals to death. This happens by about $9-10$ days of the onset of symptoms associated with EVD. Because the early symptom profile of EVD matches with other diseases like Malaria, the confused patients might report late to medical personnel. By this time a full-blown EVD manifests. One aspect of EVD is HF, characterized by copious internal bleeding, and in no time death ensues. This is the reason behind the high fatality rate (which can approach 90\%) associated with EVD.

One axiom accepted by most virologists is that a virus usually never kills the host. If it does, it cannot be transmitted further. Club this with the observation that Ebola virus rapidly kills its victims, suggests that humans are accidental hosts for this virus, and the actual natural host of the virus is yet to be identified [2]. Also, because of the high mortality rate associated with the virus, any epidemic of Ebola should 'self restrict' or 'burn out' within a short span of time. The Ebola-2014 in Equatorial Africa involving DRC conforms to this theory. In fact all epidemics of Ebola virus in DRC till date, Ebola-2014 is the seventh, conform to this accepted theory mentioned here. Ebola-2014 in West Africa deviated from the mentioned apophthegm in many aspects thereby puzzling scientists.

Before we discuss the West African Ebola-2014, few points with regard to HF. Hemorrhagic fever can be caused by at least four groups of viruses. These include Arena viruses, Filoviruses (of which Ebola is a member), Bunyaviruses and Flaviviruses (like Yellow fever virus) [3]. There is no cure or treatment for HF. Vaccine against yellow fever virus (a Flavivirus) is the only approved vaccine against $\mathrm{HF}$. Incidentally, yellow fever vaccine is also effective against Bolivian HF (caused by an Arena virus). Yellow fever is prevalent in South America and Africa, and for reason, perhaps attributable to race, it is absent in Asia. It is mandatory for travelers to South America and Africa to take yellow fever vaccine. Whether this vaccination for yellow fever is effective against $\mathrm{HF}$ induced by Ebola virus is not known. But the noteworthy point here is since the HF induced by Ebola virus is similar to the one induced by yellow fever and other viruses; it not only confuses the patients but the medical personnel as well. Therefore, accurate diagnosis, preferably at the molecular level, is essential. All of these consume time, which is vital as there is no approved treatment against EVD at present.

In stark contrast to the Ebola-2014 of DRC, the one afflicting West Africa officially confirmed to have started in March 2014, as on 25 Feb 2015, killed 9652 patients [4]. Ebola-2014 in West Africa is spread across at least four nations - Sierra Leone, Guinea, Liberia, and Nigeria. This defies the axiom mentioned earlier. Thus, there is a need to assess the situation as to what could have led to the sustenance of this multi-dimensional epidemic. Among the various contributory factors, a few are discussed here.

1. Because upon death, the virus cannot spread, for sustenance, practices associated with the dead might be one contributory factor. Maganga et al., [5] argue that funeral rites associated with EVD might be different in DRC and West Africa.

2. One contributory factor for spread of disease across nations may be in the observation that international borders might be porous. In fact many West African nations are signatories to the Economic Community of West African States (ECOWAS) treaty of 1975. This treaty enables citizens of member states free entry within 90 days (http://immigration.gov.ng).

3. Although no infectious Ebola virus was isolated from wild bats till date [6], the probability of an unidentified sylvatic animal spreading the disease across borders cannot be ruled out [7].

4. Although a number of authors disagree, the virus might be transmissible by air. At least one credible source clearly says that airborne transmission of Ebola exists. But this might not be the primary route of transmission [6]. Also, Richard Preston in his book on Ebola virus 'The Hot Zone' (published in 1989) suggests that the virus could be transmitted by air (richardpreston.net). While there is a disagreement on whether Preston's book represents fiction or not, the probability of airborne transmission cannot be ruled out entirely for this virus [8]. The observation that Ebola-2014 of DRC and West Africa are different genetically [9] points to airborne transmission. This opens up a debate on whether small changes in nucleic acid can confer the virus with an ability to get transmitted by a different route.

5. The West African region is one hot zone for diseases like Malaria, Tuberculosis (TB), and Human Immunodeficiency virus (HIV). In reality, Nigeria has the World's second largest population of people living with HIV infection [10]. India closely follows Nigeria at third place in this regard. The Nigerian angle of the epidemic perhaps indicates that Ebola-2014 occurred as a secondary infection in an already immune-compromised population. This hypothesis gains significance in the observation that one of the oldest samples of HIV has been isolated from frozen Ebola virus infected patient samples in a retrospective study [11].

While all of the above points appear convincing, in reality, Ebola-2014 in West Africa might be a cumulative manifestation of all of the above mentioned. Also, the probability of conspiracy cannot be ruled out completely taking into account the fiction listed in the preceding section and the economic indicators mentioned in the next section. Needless-to-say, the Centres for Disease control (CDC) (www.cdc.gov) lists Ebola viruses under Category A bioterrorism agents.

\subsection{Collusion Allusion}

If the conspiracy theory in the lines of the movie MI2 
were to gain an upper hand, then it becomes essential to compare the revenues of leading Pharma-Biotech Multi-National Companies (MNCs) and the gross domestic product (GDP) of the Ebola-2014 affected nations. This is what precisely Table 2 does.

From table 2 it is readily observable that except for Nigeria, the GDP of all other affected nations is either equal to or lesser than the revenues of the six MNCs listed. This projects (1) poverty, and (2) lack of productivity, in the affected nations. It may be noted that there is no vaccine against Ebola virus and the cost for developing and releasing a viable vaccine into the market is presently in the range of US\$500 million - US\$1 billion [12]. This amount incidentally also exceeds the cost of sending an orbiter to planet Mars, which as per the Indian Space Research Organization (ISRO) costs only US\$74 million in 2014 [13].

Whether there is any sinister game afoot in Ebola-2014 or not, this planet has witnessed at least three world wars (WW) in the past, and is reeling under the effects of a fourth one. To clarify, the first two WW (WW1 and WW2) are said to have been triggered by Germany. The third one is popularly referred to as 'Cold War', and is spear-headed by USA and Union of Soviet Socialist Republics (USSR). One hallmark of WW3 is that all the battles were fought in neutral zones like Afghanistan, Iraq, Korea, Vietnam, and the battleground was never really in USA or USSR. The Cold War started around 1950 and lasted until the crumbling of USSR into Russia in 1990s. Major fallout of this 'Cold War' is the unprecedented rise in terrorism throughout the world, which the President of India considers as the fourth world war (WW4) [14]. Only recently, countries like the United Kingdom (UK) have released online WW files to commemorate the 100th anniversary of WW1 [15]. The WW3 files still seem to be in cold storage.

Table 2. Comparison of gross domestic product (GDP) of the Ebola-2014 affected countries with the revenues of top six Pharma-Biotech multi-national companies (MNC).

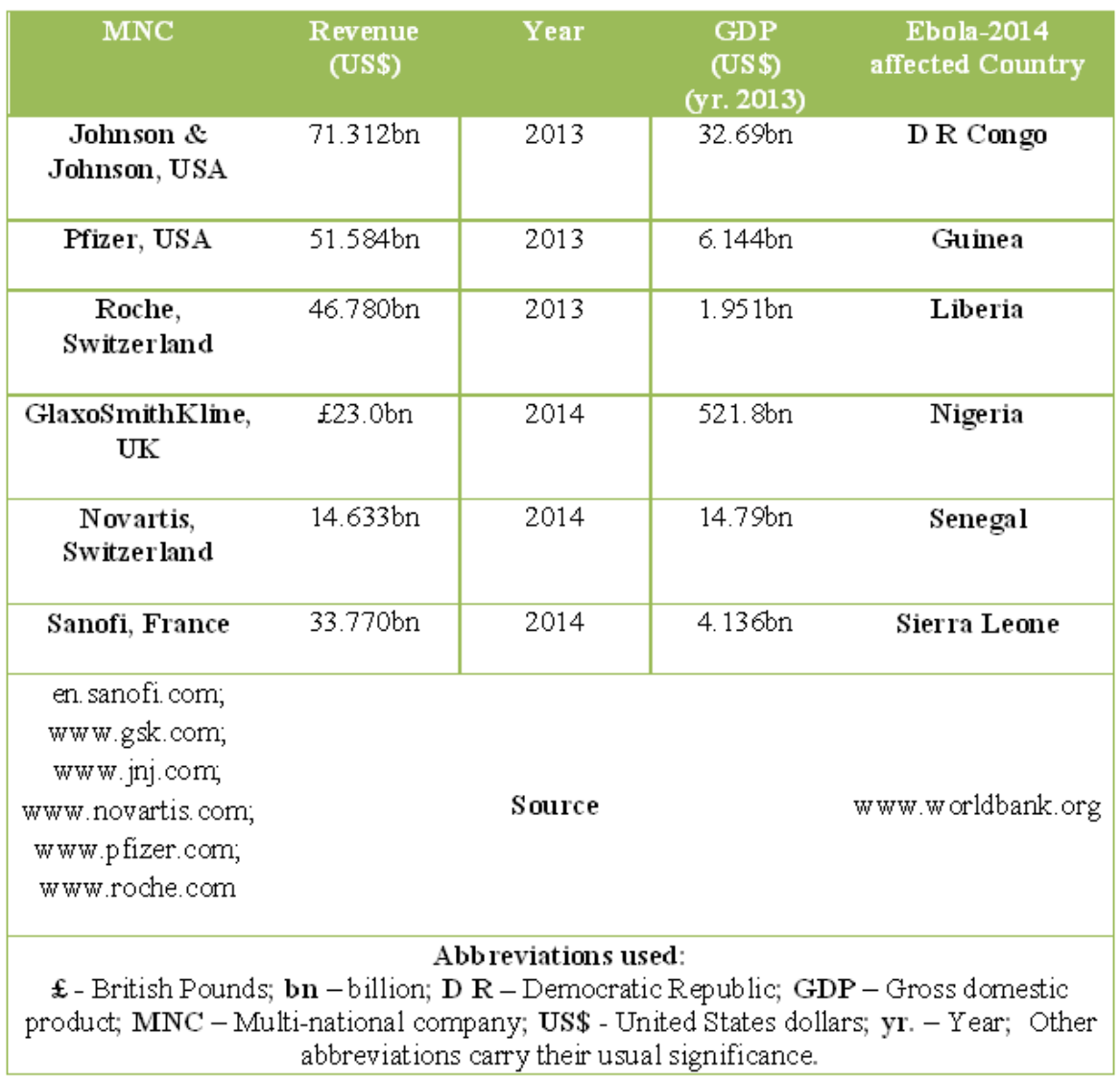




\section{Conclusion - Give the Devil his due!}

One major stumbling block in implementing safety, surveillance and modern medical practices in places like Africa is in the observation that if these interventions go wrong, there will be a heavy public backlash. Whitty [16] reported the murder of health workers and journalists in September 2014 by locals when things went wrong. Therefore, Whitty adds public buy-in is essential. To oversee such operations, UK released £200 million (US\$320 million).

On 23 May 2011, the world was momentarily poised on the brink of yet another global war. USA President Barack Obama's car, nicknamed The Beast, got stuck on a metal ramp in Dublin, Ireland. Although the President's security officials downplayed the incident saying that it was a spare limousine, video footage available in various news portals clearly show a man resembling Barack Obama disembarking from the stalled car, before a security van blocked the view [17]. Only the absence of a character like Gavrilo Princip (see Endnotes 2) ensured that the incident did not escalate into a full-fledged multinational war. Three years later with the outbreak of Ebola-2014, Obama warns United Nations (UN) in September 2014 that Ebola is a growing threat to regional and global security before deploying 4000 troops and pledging US\$750 million [18].

\section{Endnotes 1}

I intentionally use the spelling 'bellerofon' in contrast to the spelling 'bellerophon' used by various authors of different articles on the movie Mission Impossible 2. This is essentially to avoid confusion with the hero of Greek Mythology whose name is written as Bellerophon (or Bellerophontes) and thereby hurting the sentiments of believers of Greek Mythology.

\section{Endnotes 2}

Gavrilo Princip is a Bosnian Serb teenager who assassinated Archduke Franz Ferdinand on 28 June 1914, an incident which is believed to have triggered First World War. Butcher, T., The man who started the First World War. The Telegraph. www.telegraph.co.uk/history/world-war-on e/inside-first-world-war/part-one/10273752/gavrilo-princip. html. Updated 30Aug2013. Accessed 26Feb2015.

\section{Abbreviations \& Symbols Used}

£ - British Pounds (Currency); CDC - Centres for Disease control; DRC - Democratic Republic of Congo; ECOWAS - Economic Community of West African States; EVD - Ebola Virus Disease; GDP - Gross Domestic Product; HF - Hemorrhagic Fever; HIV - Human
Immunodeficiency Virus; ISRO - Indian Space Research Organization; MI2 - Mission Impossible - 2; MNC Multi-National Company; TB - Tuberculosis; UK - United Kingdom; UN - United Nations; US\$ - United States Dollars (Currency); USA - United States of America; USSR - Union of Soviet Socialist Republics; WW - World War; Other abbreviations carry their usual significance.

\section{Acknowledgements}

Helpful discussions with colleagues past and present are gratefully acknowledged. The author also wishes to acknowledge the anonymous reviewers whose comments also helped improve the article. Additional contact details of the author: Flat -501 , Highlight Haveli, Street - 6, Habsiguda, Hyderabad - 500007, Telangana, India.

Phones: +91-9492891303 \& +91-9816160830.

\section{REFERENCES}

[1] Mahishale, V. 2015. Ebola: An International Crisis. J Sci Soc, $42,1-2$.

[2] Hayden, E. C. 2014. The Ebola Questions. Nature, 514, $554-$ 557.

[3] Hoyle, B. 2004. Hemorrhagic fevers and diseases. The Gale Encyclopedia of Science. Ed. K. Lee Lerner and Brenda Wilmoth Lerner. 3rd Ed. Vol 3. Detroit: Gale, 1962 - 1965.

[4] Anonymous. 2014. Ebola Outbreak in West Africa. www.cdc.gov/inf/ebola/outbreak/2014-west-africa/ Updated 26Feb2015. Accessed 27Feb2015.

[5] Maganga, G. D., Kapetshi, J., Berthet, N., Ilunga, B. K., Kabange, F., Kingebeni, P. M., et al. 2014. Ebola virus disease in the Democratic Republic of Congo. New Engl J Med, 371, $2083-2091$.

[6] Hoyle, B. 2004b. Ebola Virus. The Gale Encyclopedia of Science. Ed. K. Lee Lerner and Brenda Wilmoth Lerner. 3rd Ed. Vol 2. Detroit: Gale, 1331 - 1333.

[7] Vogel, G. 2014. Are bats spreading Ebola across sub-Saharan Africa? Science, 344, 140.

[8] Maron, D. F. 2014. Will the Ebola virus go airborne? http://www.nature.com/news/will-the-ebola-virus-go-airborn e-1.15943. Updated 16Sept2014. Accessed 27Feb2015.

[9] Kumar, C. V. M. N., Gopal, D. V. R. S. 2014. Possible risk of outbreak in India: how well are we prepared? Curr Sci, 107 \# $6,937$.

[10] www.unaids.org/en/dataanalysis/datatools/aidsinfo/ Accessed 28Feb2015.

[11] Anonymous. 1988. Scientists isolate 'earliest HIV isolate' from 1976 serum sample in Northern Zaire. AIDS Alert 1988, 35 .

[12] Anonymous. 2009. Investing in vaccines for the developing world. Fact Sheet. www.path.org. Updated Apr2009. Accessed 26Feb2015. 
[13] Sebastian, M. 2014. ISRO successfully places Mangalyaan in Mars' orbit: India makes space history. www.dnaindia.com Updated 24Sept2014. Accessed 27Feb2015.

[14] Mukherjee, P. 2012. Speech by Shri Pranab Mukherjee on his assumption of office as president of India. Presidentofindia.nic.in/speeches-detail.htm?254. Updated 25Jul2012. Accessed 28Feb2015.

[15] Norton-Taylor, R. 2014. Top secret MI5 files released online to mark First World War centenary. The Guardian. www.theguardian.com/uk-news/2014/apr/09/mi5-files-releas ed-world-war-centenary. Updated 09Apr2014. Accessed
$28 \mathrm{Feb} 2015$.

[16] Whitty, C. J. M. 2014. Tough choices to reduce Ebola transmission. Nature, 515, $192-194$.

[17] Anonymous. 2011. Barack Obama's car, nicknamed The Beast, gets stuck. www.bbc.com/news/uk-13507728. Updated 28May2011. Accessed 26Feb2015.

[18] Oppenheimer, A. 2014. "Deploying for the Ebola war: (10/9/2014): Virus is 'a national security priority', says Obama”. Military Periscope Special Reports. Military Periscope. 